\title{
p53-dependent suppression of the human calcyclin gene (S100A6): the role of Sp1 and of $\mathrm{NF} \kappa \mathrm{B}$
}

\author{
Weronika Króliczak ${ }^{1}$, Maciej Pietrzak ${ }^{2}$ and Monika Puzianowska-Kuznicka ${ }^{1,2 \varpi ~}$ \\ ${ }^{1}$ Department of Biochemistry, Medical Center of Postgraduate Education, Warszawa, Poland; ${ }^{2}$ Department of \\ Biochemistry and Molecular Biology, Medical Research Center, Polish Academy of Sciences, Warszawa, Poland
}

Received: 20 May, 2008; revised: 11 July, 2008; accepted: 10 August, 2008 available on-line: 20 August, 2008

\begin{abstract}
Calcyclin (S100A6) is believed to participate in cell cycle control. It was, however, unclear if its expression depends on p53, a key regulator of apoptosis and cell cycle. We therefore performed transcription regulation assays in HeLa cells and found that wild type p53 suppressed the S100A6 promoter up to 12-fold in a dose-dependent manner. In contrast, the well-characterized V143A, R175H, R249S, and L344A p53 mutants cloned from human cancers suppressed this promoter with a 6 to 9-fold lower efficiency. All the sites mediating the p53-dependent suppression were contained in the -167 to +134 fragment of the S100A6 promoter. Separate overexpression of either Sp1 or of NFkB only partially counteracted the p53 inhibitory effect on the S100A6 promoter, while simultaneous overexpression of both these transactivators resulted in a complete abolishment of the p53 inhibitory effect on this promoter. Sp1 and NFKB binding to the probes resembling their putative binding sites present in the S100A6 promoter was decreased in the presence of wild type p53. We propose that the suppression of S100A6 is yet another mechanism by which p53 inhibits proliferation. Insufficient suppression of this gene by p53 mutants could well be responsible for calcyclin overexpression and cell cycle deregulation observed in cancer tissues.
\end{abstract}

Keywords: calcyclin gene (S100A6), wild type and mutant p53, gene suppression, Sp1, NFкB

\section{INTRODUCTION}

Calcyclin (also known as S100A6) seems to be involved in early phase of cell differentiation (Tonini et al., 1995), exocytosis (Thordarson et al., 1991; Okazaki et al., 1994) and, above all, in cell cycle regulation, but there are still some doubts about the precise function of this protein. Calcyclin belongs to the S100 family of calcium-binding proteins (Heizmann et al., 2002; Donato, 2003; Santamaria-Kisiel et al., 2006) and under physiological conditions it is mainly expressed in epithelial cells and fibroblasts (Kuznicki et al., 1992), in neurons (Filipek et al., 1993), and in lymphocytes (Ferrari et al., 1992). Its putative role in cell cycle regula- tion is supported by the following findings: first, the amount of calcyclin mRNA in the cell undergoing mitosis is not uniform: it is high in the late G1 phase and decreases in the S phase of the cell cycle (Hirschhorn et al., 1984); second, during late prophase, calcyclin relocates from the nuclear envelope to the cytoplasm and then it disappears (Stradal \& Gimona, 1999; Tomas \& Moss, 2003; Farnaes \& Ditzel, 2003); third, calcyclin mRNA and protein levels increase in the renal cortex during recovery after acute tubular necrosis, and the protein co-localizes with the proliferating cell nuclear antigen (PCNA) (Cheng et al., 2005). In addition, calcyclin is overexpressed in many different human cancers, such as melanoma (Weterman et al., 1993),

${ }^{\square}$ Corresponding author: Monika Puzianowska-Kuznicka, Department of Endocrinology, Medical Research Center, Polish Academy of Sciences, Stefana Banacha 1a, 02-097 Warszawa, Poland; tel: (48 22) 599 1755; fax: (48 22) 599 1975; e-mail: monika@amwaw.edu.pl

Abbreviations: BSA, bovine serum albumin; C/EBP, CCAAT/enhancer binding protein; DMEM, Dulbecco modified eagle's medium; EGFP, enhanced green fluorescent protein; FBS, fetal bovine serum; NFкB, nuclear factor kappa B; PBS, phosphate-buffered saline; p53, tumor suppressor p53; Sp1, stimulatory protein 1; S100, family of calcium binding proteins; S100A6, calcyclin; TBS, Tris-buffered saline. 
squamous cell carcinoma of the mouth (Berta et al., 1997), cholangiocarcinoma (Kim et al., 2002), colorectal adenocarcinoma (Komatsu et al., 2000; Alvarez-Chaver et al., 2007), stomach adenocarcinoma (Jang et al., 2004), pancreas cancer (Vimalachandran et al., 2005; Ohuchida et al., 2007), breast cancer (Cross et al., 2005), and papillary thyroid cancer (Brown et al., 2006). It has been suggested that the nuclear localization of calcyclin is associated with poor survival in pancreatic cancer patients (Vimalachandran et al., 2005), and high concentration of calcyclin significantly correlates with advanced stages of colorectal carcinoma (Komatsu et al., 2000) and with melanoma clinical stage and metastatic potential (Weterman et al., 1992; 1993).

Expression of the gene encoding calcyclin, S100A6, is activated by growth factors. Serum-inducible and platelet-derived growth factor-responsive sequences are contained within a 164 bp promoter fragment just upstream of the transcription start site (Ghezzo et al., 1988). To further support the hypothesis on calcyclin involvement in cell cycle control, we decided to establish if the activity of its gene depends on the action of p53, one of the major regulators of proliferation and apoptosis (Szymańska \& Hainaut, 2003). While p53-dependent activation of transcription is mediated by direct p53 binding to its recognition sequences within the target promoters, transcription suppression by p53 is exerted via a number of different mechanisms: direct p53 binding to target promoter (St Clair et al., 2004), competition with transactivators for binding to DNA (Subbaramaiah et al., 1999; Li \& Lee, 2001), or formation of complexes between p53 and other transcriptional activators leading to their sequestration or to a change in their activity or affinity for DNA (Xu et al., 2000; Sengupta et al., 2005). The transcription factor most commonly involved in the latter mechanism of transrepression by p53 is Sp1 (Webster et al., 1996; Bargonetti et al., 1997; Ohlsson et al., 1998; Xu et al., 2000; Zhang et al., 2000). Other transcription factors include C/EBP (Webster et al., 1996), NFкB (Bargonetti et al., 1997), as well as members of the basal transcriptional machinery, such as the TATA-binding protein (Seto et al., 1992; Truant et al., 1993; Subbaramaiah et al., 1999) and other general transcription factors (Ragimov et al., 1993; Xiao et al., 1994; Farmer et al., 1996).

In this paper we show that the promoter of the S100A6 gene encoding calcyclin is suppressed by wild type p53 in a dose-dependent manner, while suppression by p53 mutants cloned from human cancers is less efficient. We also provide evidence that this is a result of a dual mechanism: p53 interference with $\mathrm{Sp} 1$ and with $\mathrm{NF \kappa B}$ function on the S100A6 promoter.

\section{MATERIALS AND METHODS}

Cloning of Sp1 transcription factor. The 2355 bp human Sp1 coding sequence (GeneBank NM138473) was cloned from human cDNA (made from healthy thyroid mRNA) with Platinum $P f x$ polymerase (Invitrogen Life Technologies, Carlsbad, CA, USA) and using the following primers: $5^{\prime} \mathrm{Sp} 1$ 5'-CAGGTACCATGAGCGACCAAGATCACTC-3' (incorporated $\mathrm{KpnI}$ site in bold), 3'Sp1 5'-CACTCGAGTCAGAAGCCATTGCCACTGA-3' (incorporated XhoI site in bold) in a PCR reaction supplemented with $\mathrm{MgSO}_{4}$ up to $2 \mathrm{mM}$. After a $3 \mathrm{~min}$ initial denaturation at $94^{\circ} \mathrm{C}$, five cycles of $94^{\circ} \mathrm{C}$ for $20 \mathrm{~s}$, $55^{\circ} \mathrm{C}$ for $30 \mathrm{~s}$ and $68^{\circ} \mathrm{C}$ for $3 \mathrm{~min}$, and then 30 cycles of $94^{\circ} \mathrm{C}$ for $20 \mathrm{~s}, 58^{\circ} \mathrm{C}$ for $30 \mathrm{~s}$ and $68^{\circ} \mathrm{C}$ for $3 \mathrm{~min}$ were performed, followed by a final extension at $68^{\circ} \mathrm{C}$ for $5 \mathrm{~min}$. Once the PCR reaction was completed, 2 units of Taq polymerase was added to generate A-overhangs, and the sample was incubated at $72^{\circ} \mathrm{C}$ for $20 \mathrm{~min}$. The PCR product was then cloned into the pGEM-T vector (Promega, Madison, WI, USA), cut with $\mathrm{KpnI}$ and XhoI endonucleases and re-cloned into the pcDNA3.1(+) expression vector (Invitrogen Life Technologies, Carlsbad, CA, USA) prepared with the same enzymes. The Sp1 coding sequence was verified by restriction and sequencing.

Cloning of the -66 to +134 deletion mutant of the S100A6 promoter. The shortest, $200 \mathrm{bp}$ long deletion mutant of the S100A6 promoter (pGL2CACY $(-66 /+134))$ was cloned by PCR on a template of the vector containing the -1731 to +134 fragment of the S100A6 promoter (pGL2-CACY $(-1731 /+134)$ (a gift from Dr. Wiesława Lesniak, Nencki Institute of Experimental Biology, Warszawa, Poland; Lesniak et al., 2000), with proofreading Platinum Pfx polymerase, the forward primer 5'TACACGAGCTTGGCCGAGCTGGCCT3' (XhoI restriction site in bold) and the reverse primer 5'-AGAAGCTTGATCCAGCGGCTGAACTGG-3' (HindIII restriction site in bold). The cycles were as follows: $94^{\circ} \mathrm{C}$ for $3 \mathrm{~min}$, five cycles of $94^{\circ} \mathrm{C}$ for $20 \mathrm{~s}, 56^{\circ} \mathrm{C}$ for $30 \mathrm{~s}, 68^{\circ} \mathrm{C}$ for 1 min, 30 cycles of $94^{\circ} \mathrm{C}$ for $20 \mathrm{~s}, 58^{\circ} \mathrm{C}$ for $30 \mathrm{~s}, 68^{\circ} \mathrm{C}$ for $1 \mathrm{~min}$, final extension at $68^{\circ} \mathrm{C}$ for $5 \mathrm{~min}$. To produce A-overhangs at $3^{\prime}$ ends of PCR product, 2 units of Taq polymerase was then added, and the sample was incubated at $72^{\circ} \mathrm{C}$ for $20 \mathrm{~min}$. The product of the reaction was cloned into the pGEM-T vector, restricted out with XhoI and HindIII enzymes, and recloned into the pGL2-Basic vector (Promega, Madison, WI, USA) cut with the same enzymes.

Cloning of the pEGFP-CACY $(-1731 /+134)$ reporter plasmid. The -1731 to +134 fragment of the S100A6 promoter was amplified on the template of pGL2-CACY $(-1731 /+134)$ with Platinum Pfx polymerase, and with 5'-TCGAACGTAGAGTACTCGGTGTTCCTGAG-3' forward and 5'-TCGAACGTAG- 
GGATCCAGCGGCTGAAC-3' reverse primers (ScaI and BamHI restriction sites in bold, respectively). The cycles were: $94^{\circ} \mathrm{C}$ for $2 \mathrm{~min}, 20$ cycles of $94^{\circ} \mathrm{C}$ for $20 \mathrm{~s}, 68^{\circ} \mathrm{C}$ for $2 \mathrm{~min}$, and the final extension at $68^{\circ} \mathrm{C}$ for $5 \mathrm{~min}$. To produce A-overhangs at the $3^{\prime}$ ends of the PCR product, 2 units of Taq polymerase was added, and the sample was incubated at $72^{\circ} \mathrm{C}$ for $20 \mathrm{~min}$. The product of the reaction was cloned into pGEM-T vector, and restricted out with ScaI and BamHI. pEGFP-N1 vector (Clontech Laboratories, Mountain View, CA, USA) was restricted with AseI, and the overhanging ends were blunted with the Klenow enzyme. After gel purification, the vector was restricted with BamHI. The PCR product was ligated into this vector, producing a pEGFPCACY $(-1731 /+134)$ reporter plasmid.

Mutagenesis of the $S 100 A 6$ promoter. A 38 bp GC-rich fragment located at positions -100 to -63 of the $\$ 100 A 6$ promoter (5'-GGGTGGGGCGCGGGCGGGACTTGGGCGGGCGGGGTGGG-3'), containing putative Sp1 binding sites, was removed by PCR from the $1.5 \mathrm{~kb}$ promoter fragment. Initially, two fragments of this promoter were cloned. The first one flanking the GC-rich sequence from the 5 '- side was cloned with the following primers: $5^{\prime}$ cacy 5'-TCGAACGTAGAGTACTCGGTGTTCCTGAG-3' (ScaI restriction site in bold) and -3'cacyint 5'-AGCTCGGCCAAG//TGCGCCGTGGCTTACAC-3' consisting of the sequences flanking the GC-rich promoter fragment from both sides (// shows the border of the two sequences), while the second one located at the $-3^{\prime}$ side of the GC-rich fragment was cloned with the following primers: $5^{\prime}$-cacyint $5^{\prime}$-AGCCACGGCGCA//CTTGGCCGAGCTGGCCT-3' consisting of the sequences flanking promoter fragment to be removed (// shows the border of the two sequences) and -3'cacy 5'-TCGAACGTAGGGATCCAGCGGCTGAAC-3' (BamHI restriction site in bold). The products of these PCRs were resolved on 1\% agarose gel. The bands of approx. $1.25 \mathrm{~kb}$ (the first S100A6 promoter fragment) and $200 \mathrm{bp}$ (the second fragment) were excised and incubated separately in $100 \mu \mathrm{l}$ of $\mathrm{dH}_{2} \mathrm{O}$ for $4 \mathrm{~h}$. Aliquots of $4 \mu \mathrm{l}$ from each fragment were pooled and used as a template in a second round of PCR performed with 5'-cacy and -3'cacy primers. All PCRs were performed with proofreading Platinum Pfx polymerase. The cycles of the first round of PCR were as follows: $94^{\circ} \mathrm{C}$ for $2 \mathrm{~min}$, five ycles of $94^{\circ} \mathrm{C}$ for $20 \mathrm{~s}, 58^{\circ} \mathrm{C}$ for $30 \mathrm{~s}, 68^{\circ} \mathrm{C}$ for $2 \mathrm{~min}$, 25 cycles of $94^{\circ} \mathrm{C}$ for $20 \mathrm{~s}, 68^{\circ} \mathrm{C}$ for $2 \mathrm{~min}$, and the final extension at $68^{\circ} \mathrm{C}$ for $5 \mathrm{~min}$. The cycles of the second PCR were: $94^{\circ} \mathrm{C}$ for $2 \mathrm{~min}, 30$ cycles of $94^{\circ} \mathrm{C}$ for $20 \mathrm{~s}, 68^{\circ} \mathrm{C}$ for $2 \mathrm{~min}$, and the final extension at $68^{\circ} \mathrm{C}$ for $5 \mathrm{~min}$. The product of the second round of PCR was cut with ScaI and BamHI enzymes, while pGL2 basic vector was cut with SmaI and BglII enzymes. Both DNAs were ligated producing pGL2-CACY(-

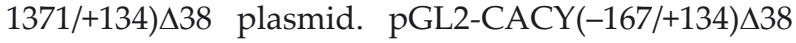
was prepared from pGL2-CACY $(-1371 /+134) \Delta 38$ by restriction of a $263 \mathrm{bp}$ long promoter fragment (-167 to +134$)$ with SmaI and HindIII enzymes, and its ligation into the pGL2-basic vector prepared with the same enzymes.

Cell culture. HeLa cells were grown in high glucose Dulbecco Modified Eagle's Medium (DMEM, Sigma-Aldrich, St. Louis, MO, USA) supplemented with $10 \%$ heat-inactivated fetal bovine serum (FBS), with or without $100 \mathrm{u} / \mathrm{ml}$ penicillin $\mathrm{G}$ and $100 \mu \mathrm{g} / \mathrm{ml}$ streptomycin. Cells were incubated in a humidified incubator at $37^{\circ} \mathrm{C}$ in $5 \% \mathrm{CO}_{2}$.

Transient transfections. HeLa cells were seeded 1:2 onto a 24-well dish and maintained without antibiotics for $24 \mathrm{~h}$ before transfection. Cells were transfected with $1.5 \mu$ l Metafectene (Biontex Laboratories $\mathrm{GmbH}$, Munich, Germany), with 250 ng reporter vector pGL2-CACY containing the S100A6 promoter fragments -1371 to $+134,-588$ to +134 , -365 to $+134,-167$ to +134 (a gift from Dr. Wiesława Lesniak, Nencki Institute of Experimental Biology, Warszawa, Poland), or -66 to $+134,20$ ng phRLCMV internal control vector (Promega, Madison, WI, USA), and with 20-250 ng CMV-p53 expression vector encoding wild type human p53, or with $100 \mathrm{ng}$ of the vector encoding mutant p53 (a gifts from Professor Maciej Zylicz, International Institute of Molecular and Cell Biology, Warszawa, Poland). When necessary, co-transfections were performed with 20-250 ng pcDNA3.1(+)-Sp1 expression vector encoding human Sp1, or with 50-150 ng pcDNA3.1(+)NFкB p50 and 2.5-100 ng pcDNA3.1(+)-NFkB p65 (provided by Dr. Jochen Seufert, Medical Policlinic of the University of Wuerzburg, Germany). Control transfections were performed with pGL2-basic and pcDNA3.1(+) vectors. Metafectene and DNA were diluted separately in $20 \mu \mathrm{l}$ of plain DMEM, mixed, incubated at room temperature for $20 \mathrm{~min}$, and then added to HeLa cells. After $24 \mathrm{~h}$ incubation, the cells were washed with phosphate buffered saline (PBS) and lysed at room temperature for 20 min with 100 $\mu \mathrm{l}$ passive lysis buffer (Promega, Madison, WI, USA) added directly to the cells. Firefly luciferase and Renilla luciferase activities were measured in a microplate luminometer (BMG Labtech, Offenburg, Germany). Each experiment was repeated 9 to 12 times.

Immunofluorescence. HeLa cells $\left(10^{4}\right)$ were seeded onto glass coverslips (soaked in $70 \%$ ethanol for $3 \mathrm{~h}$ and air-dried) placed into a 24-well dish. The cells were transfected $24 \mathrm{~h}$ later with $250 \mathrm{ng}$ pEGFPCACY $(-1371 /+134)$ reporter plasmid containing EGFP reporter gene placed under the control of the -1371 to +134 fragment of the $S 100 A 6$ promoter, and with $100 \mathrm{ng}$ CMV-p53 plasmid or with $100 \mathrm{ng}$ of 'empty' pcDNA3.1(+) vector. After $24 \mathrm{~h}$ incubation, the cells were washed 3 times with PBS, fixed for 10 
$\min$ at $4^{\circ} \mathrm{C}$ with $2 \%$ paraformaldehyde, incubated for $10 \mathrm{~min}$ at room temperature in $0.1 \%$ Triton X-100 in PBS, and washed again 3 times in PBS for $1 \mathrm{~min}$. The cells were then incubated in 2\% BSA in PBS for $1 \mathrm{~h}$ at room temperature, incubated for $1 \mathrm{~h}$ at room temperature in a humidified chamber with a primary anti-p53 mouse monoclonal antibody (1:500 in $2 \%$ BSA in PBS; DO1, Oncogene Science, Inc., Cambridge, MA, USA), washed 3 times in $2 \%$ BSA in PBS, and incubated for $1 \mathrm{~h}$ in a humidified chamber in the dark with Alexa Fluor 594 goat anti-mouse secondary antibody (1:1000 in 2\% BSA in PBS; Invitrogen Molecular Probes, Eugene, OR, USA). After 3 further washes with $2 \%$ BSA in PBS (twice for 40 $\min$ at room temperature, and once for $16 \mathrm{~h}$ at $4^{\circ} \mathrm{C}$ ), the coverslips were mounted with SlowFade Light Antifade Reagent (Invitrogen Molecular Probes, Eugene, OR, USA) and sealed with acetone-free nail polish. The cells were analyzed under a fluorescence microscope.

Whole-cell protein isolation from HeLa cells and Western blotting. HeLa cells $\left(2 \times 10^{5}\right)$ were suspended in $70 \mu \mathrm{l}$ of lysis buffer consisting of $75 \mathrm{mM}$ Tris/ $\mathrm{HCl}, \mathrm{pH}$ 8.0, 2\% SDS, $15 \%$ glycerol, and boiled for $5 \mathrm{~min}$. Forty micrograms of protein extract was supplemented with $\beta$-mercaptoethanol to $5 \%$ and bromophenol blue to $0.01 \%$, boiled, and loaded onto a 10\% polyacrylamide gel. Proteins were transferred onto a nitrocellulose membrane (Bio-Rad Laboratories, Inc., Hercules, CA, USA). The protein loading and integrity were monitored by Ponceau Red staining. The destained membrane was blocked overnight at $4^{\circ} \mathrm{C}$ in $5 \%$ nonfat dry milk solution in TBS-T (Tris-buffered saline (TBS) supplemented with $0.1 \%$ Tween 20), washed at room temperature in TBS-T once for $15 \mathrm{~min}$ and twice for $5 \mathrm{~min}$, incubated with a mouse monoclonal anti-p53 antibody (1:10000 in TBS-T; DO1, Oncogene Science, Inc., Cambridge, MA, USA), or a rabbit polyclonal anti-Sp1 antibody (1:2500 in TBS-T; Santa Cruz Biotechnology, Inc., Santa Cruz, CA, USA), or a rabbit polyclonal antip65 NFкB antibody (1:5000 in TBS-T; Santa Cruz Biotechnology, Inc., Santa Cruz, CA, USA), or a monoclonal anti- $\beta$-actin antibody (1:10000 in TBS-T; SigmaAldrich, St. Louis, MO, USA) for $1 \mathrm{~h}$ at room temperature, washed as before, then incubated at room temperature for $1 \mathrm{~h}$ either with a goat anti-mouse horseradish peroxidase-conjugated polyclonal antibody (1:10000 in TBS-T; Calbiochem, San Diego, CA, USA), or a goat anti-rabbit horseradish peroxidaseconjugated polyclonal antibody (1:10000 in TBST; Calbiochem, San Diego, CA, USA), respectively. Specific bands were visualized by chemiluminescent reaction performed with an ECL kit (Amersham Biosciences UK Limited, Little Chalfont, England). The blots were exposed against the film (Biomax MS, Eastman Kodak Company, Rochester, NY, USA) for
$15 \mathrm{~s}$ to $3 \mathrm{~min}$. Relative amounts of the receptor proteins were estimated from the densitometric measurements of the intensity of the specific bands normalized against the intensity of $\beta$-actin band.

Isolation of nuclear proteins. A $10 \mathrm{~cm}$-diameter dish with HeLa cells (approx. $5 \times 10^{6}$ cells) was washed twice with PBS. The cells were then scrapped off, suspended in $500 \mu \mathrm{l}$ of buffer A consisting of 10 mM Hepes, $\mathrm{pH}$ 7.9, $10 \mathrm{mM} \mathrm{KCl}, 1.5 \mathrm{mM} \mathrm{MgCl}$, supplemented with a protease inhibitors mix (Complete Protease Inhibitor Cocktail, Roche Applied Science, Basel, Switzerland) and PMSF (phenylmethylsulfonyl fluoride) to $400 \mu \mathrm{M}$, and incubated on ice for $1 \mathrm{~h}$. After incubation, the cells were homogenized in an ice-cold glass-teflon homogenizer. The resulting homogenate was transferred to an Eppendorf tube and centrifuged at $400 \times g$ for $5 \mathrm{~min}$ at $4^{\circ} \mathrm{C}$. The pellet was resuspended in an equal volume of buffer $A$, centrifuged as before, and again resuspended in two volumes of buffer B consisting of $20 \mathrm{mM}$ Hepes, $\mathrm{pH} 7.9,10 \%$ glycerol, $420 \mathrm{mM} \mathrm{NaCl}, 1.5 \mathrm{mM} \mathrm{MgCl}_{2}$, $0.2 \mathrm{mM}$ EDTA, supplemented with protease inhibitors as above. After a $30 \mathrm{~min}$ incubation on ice, the sample was centrifuged at $15000 \times g$ for $20 \mathrm{~min}$ at $4^{\circ} \mathrm{C}$, then the supernatant was transferred to a new tube and supplemented with an equal volume of buffer C consisting of $20 \mathrm{mM}$ Hepes, pH 7.9, 30\% glycerol, $1.5 \mathrm{mM} \mathrm{MgCl}, 0.2 \mathrm{mM}$ EDTA, and protease inhibitors. The sample containing soluble nuclear proteins was aliquoted into pre-chilled Eppendorf tubes, flash-frozen in liquid nitrogen, and stored at $-80^{\circ} \mathrm{C}$.

Electrophoretic mobility shift assay. The assays were performed with control HeLa nuclear extracts and with nuclear extracts made from HeLa cells transfected with p53 expression plasmid $24 \mathrm{~h}$ before protein isolation, or HeLa cells treated with camptothecin $(6 \mu \mathrm{M}$ final) for the same period. The probes were identical to the $\$ 100 A 6$ promoter fragments containing putative p53, Sp1 and NFkB binding sites (TESS, Transcription Element Search Software, Technical Report CBIL-TR-1997-1001-v0.0). The probes were made by hybridization of two complementary oligos as follows: for p53 DR-1: 5'-TAGGCAGGCAGGCCTGACTTGTC$3^{\prime}$ and 5'-CTGTGGACAAGTCAGGCCTGCC-3', for p53-DR13: 5'-GGCCTGACTTGTCCACAGCTCACCCGGAGGCCACC-3' and 5'-GCTGCCAAGGTGGCCTCCGGGTGAGCTGTGGACAAGTC-3', for p53-DR17: 5'-CCGGAGGCCACCTTGGCAGCACCTGTAGGAAGGGCATG-3' and 5'-GGCCGACATGCCCTTCCTACAGGTGCTGCCAAGGTGGCC-3', for p53-DR0: 5'-AGGTGGGCTTGGCCGAGCTGGCC$3^{\prime}$ and 5'-CCGGAGGCCAGCTCGGCCAAGCCC-3', for 1Sp1: 5'-CGGCGCAGGGTGGGGCGCGGGCGGG-3' and 5'-GCCCAAGTCCCGCCCGCGCCCCACCC-3', 
for 2Sp1: 5'-GGACTTGGGCGGGCGGGGTGG-3' and 5'-GCCAAGCCCACCCCGCCCGCC-3',

for NFKB: 5'-GGAGCCCTGGGTACTTTCCAGG-3' and 5'-GCAGCTGGCCCTGGAAAGTACCCAGG-3' .

Double stranded DNA was labeled by fill-in reaction with the Klenow fragment and $\left[\alpha-{ }^{32} \mathrm{P}\right] \mathrm{dCTP}$. Two to five micrograms of each nuclear extract was incubated at room temperature for $20 \mathrm{~min}$ in binding buffers consisting of: $10 \mathrm{mM}$ Tris, $\mathrm{pH}$ 7.9, 50 $\mathrm{mM} \mathrm{NaCl}, 2 \mathrm{mM} \mathrm{MgCl}$, $1 \mathrm{mM}$ DTT (dithiothreitol), $0.1 \mathrm{mM}$ EDTA, $0.05 \%$ Nonindet P-40, 5\% glycerol for p53 binding; $20 \mathrm{mM}$ Hepes, pH 7.9, $50 \mathrm{mM} \mathrm{NaCl}, 2$ $\mathrm{mM} \mathrm{MgCl} 2,1 \mathrm{mM}$ DTT, $0.5 \mathrm{mM}$ EDTA, $0.01 \%$ Nonindet $\mathrm{P}-40,5 \%$ glycerol for Sp1 binding; $10 \mathrm{mM}$ Tris, $\mathrm{pH} 7.5,50 \mathrm{mM} \mathrm{KCl}, 1 \mathrm{mM} \mathrm{MgCl}{ }_{2}, 0.5 \mathrm{mM}$ DTT, 0.5 mM EDTA, $0.1 \%$ Triton X-100, 5\% glycerol for NFKB binding, in the presence of $250 \mathrm{ng}$ dIdC, $0.5 \mathrm{ng}$ probe, and protease inhibitors. If required, the samples were additionally supplemented with 25 -fold excess of a specific competitor (cold probe, or, for p53 binding, a consensus p53 binding site 5'-GAGTTAGACATGCCTAGACATGCCTAACTC-3'), or of a non-specific competitor (5'-CCTGCTGATCTATCAGCACAGATTAG-3'). For supershift experiments, the reactions were incubated with $200 \mathrm{ng}$ monoclonal anti-p53, or $2 \mu \mathrm{g}$ anti-Sp1, or anti-NFkB p65 antibodies in the respective binding buffer in the presence of dIdC. After $50 \mathrm{~min}$ on ice, the respective probes were added and the incubation was continued for an additional $20 \mathrm{~min}$ at room temperature. The products of the reaction were resolved on a $5 \%$ na- tive gel. Gels were then dried and exposed against the film (Biomax MS, Eastman Kodak Company, Rochester, NY, USA) for $4-24 \mathrm{~h}$ at $-80^{\circ} \mathrm{C}$.

\section{RESULTS}

\section{p53 suppresses the human $S 100 A 6$ promoter}

Initially, to verify that p53 expressed from CMV-p53 plasmid was functional in the transfected HeLa cells that weakly express endogenous p53 (Hoppe-Seyler \& Butz, 1993), we performed immunoblot analysis of the cells transfected with this plasmid (Fig. 1A), and control transcription regulation assays with this plasmid and with pGL3-p53BS reporter plasmid containing a p53BS synthetic promoter with consensus p53 binding sites (a gift from Professor Maciej Zylicz, International Institute of Molecular and Cell Biology, Warszawa). They showed that in the presence of overexpressed p53, the activity of the reporter gene increased approx. 16-fold (Fig. 1B).

To address the question of regulation of the human S100A6 promoter by p53, the pGL2CACY $(-1371 /+134)$ reporter plasmid, containing a $1505 \mathrm{bp}$ fragment of the human S100A6 promoter, was transfected into HeLa cells together with increasing amounts of the CMV-p53 expression vector. These experiments showed that the inhibition of the
A

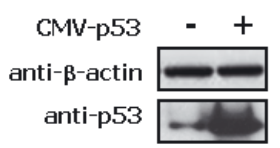

C

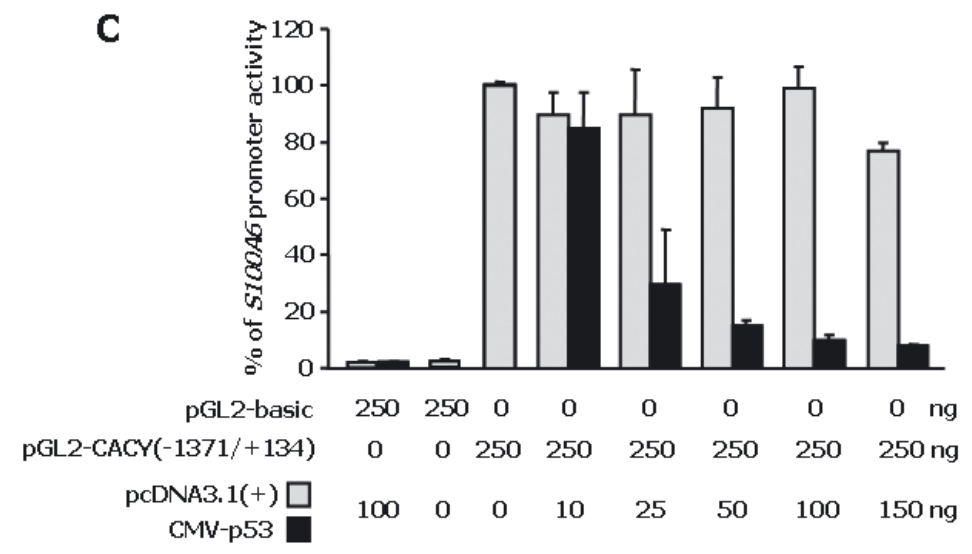

B

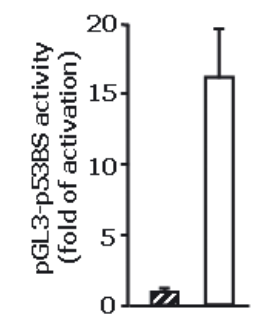

pGL3-p53BS $125125 \mathrm{ng}$

CMV-p53 $0 \quad 50 \mathrm{ng}$

pCDNA3.1(+) $50 \quad 0 \quad \mathrm{ng}$
Figure 1. Human calcyclin (S100A6) promoter is inhibited by p53.

(A) Immunoblots of whole-cell extracts made from control HeLa cells, and from HeLa cells overexpressing p53. The blots were probed with anti-p53 antibody and re-probed with anti- $\beta$-actin antibody. (B) HeLa cells transfected with CMV-p53 vector overexpress transcriptionally active p53 protein. HeLa cells were transfected with pGL3-p53BS reporter vector with the promoter containing consensus p53 binding sites, as well as with CMVp53 expression vector encoding wild type p53. (C) The S100A6 promoter is inhibited by p53 in a dose-dependent manner. HeLa cells were transfected with pGL2-CACY $(-1371 /+134)$ reporter vector, with increasing amounts of CMV-p53 expression vector or with equal amounts of 'empty' pcDNA3.1(+) vector, and with phRL-CMV internal control vector. Firefly luciferase activity was measured $24 \mathrm{~h}$ post-transfection, and the results normalized against Renilla luciferase activity. Bars represent the mean result ( \pm standard deviation) of 9 experiments performed with two different DNA preparations. 
S100A6 promoter was p53 dose-dependent and that the $S 100 A 6$ promoter was suppressed up to 12 -fold ( $8 \%$ of its activity without p53). In the presence of an 'empty' pcDNA3.1(+) vector, the $\$ 100 A 6$ promoter activity remained unaltered, providing that no more than $100 \mathrm{ng}$ of this vector was used (Fig. 1C). Transfection with higher amounts of the expression construct resulted in a slight, non-specific promoter suppression. Based on the above results, we decided to use $100 \mathrm{ng}$ of CMV-p53 in all subsequent experiments. This amount of expression vector caused an 8 -fold suppression of the $S 100 A 6$ promoter after $24 \mathrm{~h}$ incubation.

To corroborate the above result with a different method, we designed an experiment in which HeLa cells were transfected with pEGFP-CACY $(-1731 /+134)$ reporter vector encoding EGFP protein under the control of the S100A6 promoter, and either with the CMV-p53 expression vector, or with an equal amount of 'empty' pcDNA3.1(+). The relative amount of EGFP protein was assessed $24 \mathrm{~h}$ later under a fluorescence microscope in the cells transfected with the reporter and pcDNA3.1(+) vectors $v s$. cells transfected with the reporter and p53 expression plasmids. A direct comparison of both cell types was not possible, because the single and double transfections had to be performed separately, and, for this reason, the cells were grown on coverslips placed in separate wells. However, both coverslips were identically processed for immunofluorescence. Therefore, both cell types had identical controls, i.e. neighboring, not-transfected cells. Using them as go-between controls, we found that the cells transfected with the EGFP reporter vector and with pcDNA3.1(+) expressed high levels

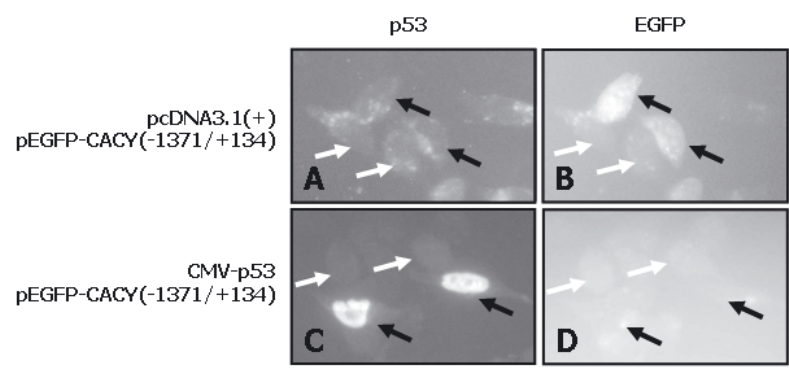

Figure 2. Overexpressed p53 inhibits EGFP expression driven by the $S 100 A 6$ promoter.

HeLa cells were transfected with pEGFP-CACY $(-1371 /+134)$ reporter vector, either with $\mathrm{CMV}$-p53 expression vector, or with an 'empty' pcDNA3.1(+) vector, probed with antip53 antibodies, and analyzed under a fluorescence microscope for the presence of p53 and EGFP proteins. (A) Cells transfected with pEGFP-CACY $(-1371 /+134)$ and with pcDNA3.1(+) vectors, analyzed for the presence of p53. (B) The same cells analyzed for the presence of EGFP. (C) Cells transfected with pEGFP-CACY $(-1371 /+134)$ and CMV-p53 vectors, analyzed for the presence of p53. (D) The same cells analyzed for the presence of EGFP. Black arrows, transfected cells. White arrows, non-transfected control cells. of EGFP protein in the cytoplasm (Fig. 2B, black arrows). In contrast, the cells transfected with the EGFP reporter vector and the CMV-p53 expression plasmid, and, therefore, overexpressing p53 in the nucleus (Fig. 2C, black arrows), did not express EGFP, judging by the absence of a specific immunofluorescent signal in their cytoplasm (Fig. 2D, black arrow), a situation identical to that observed in control cells that had not been transfected (Fig. 2D, white arrows).

\section{p53 mutants cloned from human cancers weakly suppress the S100A6 promoter}

We then proceeded to establish whether common p53 mutants cloned from human cancers suppress the S100A6 promoter. HeLa cells were therefore transfected with pGL2-CACY $(-1371 /+134)$ reporter vector and expression vectors encoding either wild type p53 or well-characterized DNA-binding domain mutants (V143A, R175H, and R249S), or a tetramerization domain mutant (L344A) (Hernandez-Boussard et al., 1999; Strano et al., 2007; Petitjean et al., 2007). All examined mutants suppressed the S100A6 promoter activity only to $60-90 \%$ of its activity without p53, showing that they were 6 to 9fold less effective than the wild type p53 (Fig. 3).

A

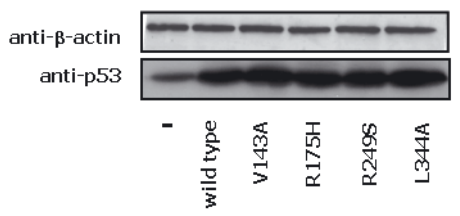

B
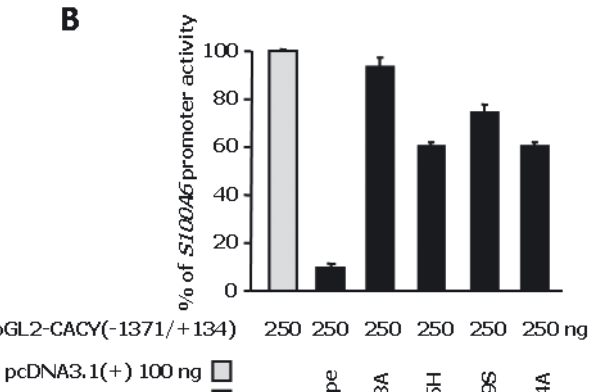

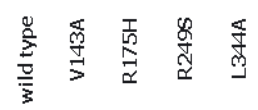

Figure 3. p53 mutants suppress the S100A6 promoter 6 to 9-fold less than wild type p53.

(A) Immunoblots of protein extracts made from control HeLa cells as well as HeLa cells overexpressing wild type and mutant p53. The blots were probed with anti-p53 antibody and re-probed with anti- $\beta$-actin antibody. (B) p53 mutants weakly inhibit the $S 100 A 6$ promoter. HeLa cells were transfected with pGL2-CACY $(-1371 /+134)$ reporter plasmid, with CMV-p53 expression plasmid encoding either wild type or mutant p53, and with phRL-CMV internal control vector. Firefly luciferase activity was measured $24 \mathrm{~h}$ post-transfection, and the results were normalized against Renilla luciferase activity. Bars represent the mean result ( \pm standard deviation) of 6 experiments. 
A

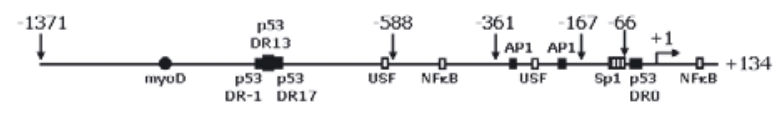

B

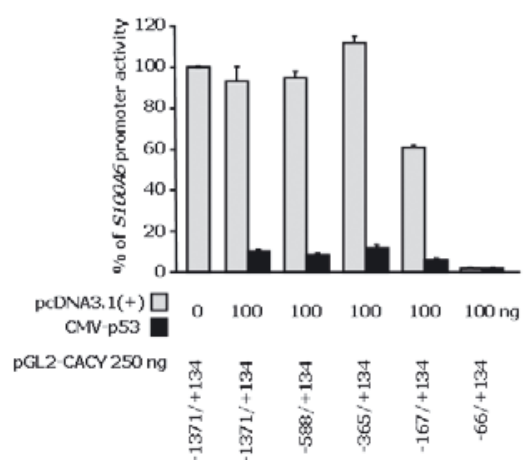

Figure 4. Deletion of three out of four promoter fragments similar to p53-specific sequences has no effect on S100A6 promoter inhibition by $\mathrm{p} 53$.

(A) Schematic presentation of the -1371 to +134 S100A6 promoter fragment and the localization of the selected putative transcription factor binding sites. The arrows point to $5^{\prime}$ ends of the deletion mutants. +1 , transcription start site. (B) The -167 to +134 fragment contains all sites mediating p53 inhibitory effect on the $S 100 A 6$ promoter. HeLa cells were transfected with pGL2 reporter construct containing different deletion mutants of the S100A6 promoter, with CMV-p53 expression plasmid encoding wild type human p53 or 'empty' pcDNA3.1(+) vector, and with phRLCMV internal control vector. Firefly luciferase activity was measured $24 \mathrm{~h}$ post-transfection and the results were normalized against Renilla luciferase activity. Bars represent the mean result ( \pm standard deviation) of 9 experiments performed with two different DNA preparations.

The -167 to +134 fragment of the $S 100 A 6$ promoter contains all sites mediating p53-dependent suppression

In order to find the region of the $\$ 100 A 6$ promoter mediating the suppression exerted by p53, we used promoter deletion mutants $(-1371 /+134$, $-588 /+134, \quad-365 /+134,-167 /+134$, and $-66 /+134$, Fig. 4A) in transcription regulation assays. The assays were performed as described above. Deletion of subsequent fragments from the $5^{\prime}$ end of the S100A6 promoter had a weak influence on the promoter's activity; only shortening of the promoter to the -167 position resulted in a $40 \%$ decrease of its activity. Deletion of the subsequent $101 \mathrm{bp}$ to the -66 position resulted in the complete silencing of the S100A6 promoter. With the exception of the inactive -66 to +134 fragment, each promoter fragment was suppressed by p53 to the same extent, i.e. approx. 8 -fold (Fig. 4B). This data indicate that the three deleted putative p53-binding sites (DR-1, DR13, DR17, located at positions -846 to -828 , the -837 to -805 , and -814 to -778 , respectively, Fig. $4 \mathrm{~A}$ ) did not mediate the S100A6 promoter inhibition by p53. Fur- thermore, lack of a direct involvement of p53 in this process was confirmed by the negative result of electrophoretic mobility shift assays performed with HeLa nuclear extracts containing overexpressed p53, and with the probes resembling the four putative p53-binding sites present in the S100A6 promoter (the three described above, and the fourth located at position -65 to -46 , DR0, Fig. 4 A). No specific binding was observed (not shown).

Taken together, these results indicate that the -167 to +134 promoter fragment contains all the sequences mediating the p53-dependent suppression of the S100A6 transcriptional activity.

\section{Deletion of a GC-rich region located at position -100 to -63 decreases the level of p53-induced S100A6 promoter suppression}

The -167 to +134 S100A6 promoter fragment differs from the -66 to +134 fragment by $101 \mathrm{bp}$ including the $38 \mathrm{bp}$ long GC-rich sequence located at the -100 to -63 position, containing six overlapping putative Sp1-binding sites. To determine if this sequence is important for p53-dependent suppression of the S100A6 activity, transcription regulation assays were performed with pGL2-CACY($1371 /+134) \Delta 38$, and with pGL2-CACY $(-167 /+134) \Delta 38$ plasmids devoid of this sequence (Fig. 5). The deletion of the GC-rich sequence decreased the overall promoter activity by approx. 50\%. Importantly, deletion of the putative Sp1-binding sites decreased

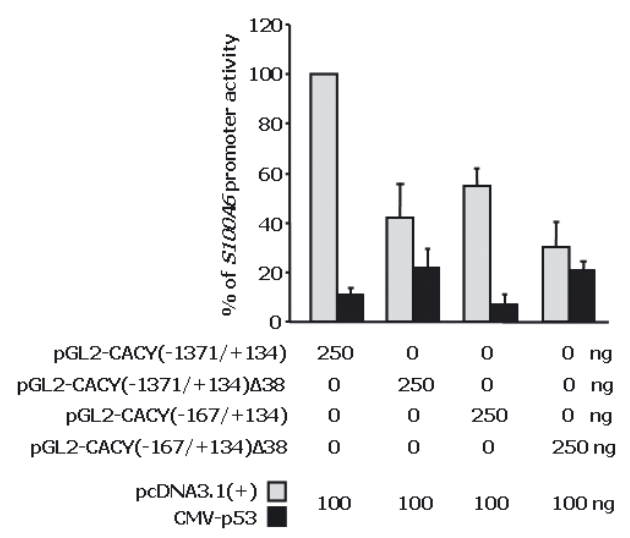

Figure 5. Deletion of the $38 \mathrm{bp}$ GC-rich region located at position -100 to -63 weakens p53-dependent inhibition of the S100A6 promoter.

HeLa cells were transfected with pGL2-CACY $(-1371 /+134)$ or pGL2-CACY $(-167 /+134)$ plasmids, or with pGL2CACY $(-1371 /+134) \Delta 38$ or pGL2-CACY $(-167 /+134) \Delta 38$ plasmids bearing the $S 100 A 6$ promoter fragments devoid of the 38 bp-long GC-rich region, with CMV-p53 expression construct encoding wild type p53 or 'empty' pcDNA3.1(+) vector, and with phRL-CMV internal control vector. Firefly luciferase activity was measured $24 \mathrm{~h}$ post-transfection and the results were normalized against Renilla luciferase activity. Bars represent the mean result ( \pm standard deviation) of 6 experiments. 
A

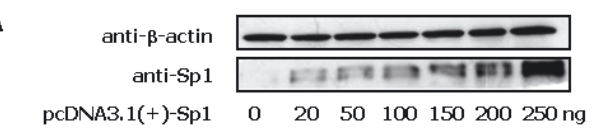

B

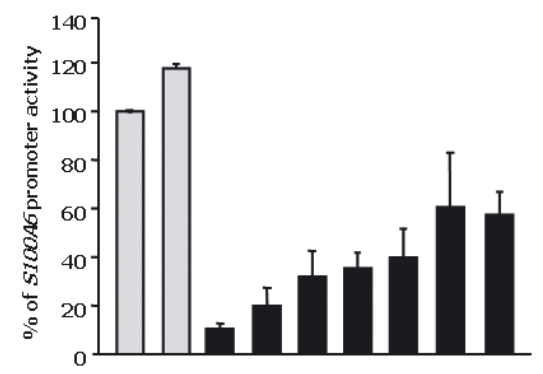

pGL2-CACY(-1371/+134) $250250250250250250250250250 \mathrm{ng}$ CMV-53 $\quad 0 \quad 0 \quad 100100100100100100100 \mathrm{ng}$ pcDNA3.1(+)-Sp1 $\quad 0 \quad 100 \quad 0 \quad 20 \quad 50 \quad 100 \quad 150 \quad 200250 \mathrm{ng}$ pCDNA3.1(+) $35025025023020015010050 \quad 0 \quad \mathrm{ng}$

Figure 6. Overexpression of $S p 1$ partially counteracts the p53 inhibitory effect on the S100A6 promoter.

(A) Immunoblots of whole-cell extracts made from control HeLa cells as well as HeLa cells overexpressing p53 and different amounts of Sp1 were probed with anti-Sp1 antibody. Duplicate blots were re-probed with anti- $\beta$-actin antibody. (B) Overexpression of Sp1 counteracts the p53-dependent inhibition of the S100A6 promoter in a dose-dependent manner. HeLa cells were transfected with pGL2-CACY (-1371/+134) reporter plasmid, with CMV-p53 expression plasmid encoding wild type human p53, with different amounts of pcDNA3.1(+)-Sp1 expression plasmid encoding wild type human Sp1, with phRL-CMV internal control vector, and, to equalize the total amount of DNA in each sample, with different amounts of pcDNA3.1(+). Firefly luciferase activity was measured $24 \mathrm{~h}$ post-transfection and the results were normalized against Renilla luciferase activity. Bars represent the mean result $( \pm$ standard deviation) of 9 experiments.

the level of promoter suppression by p53 from 8 to 2-fold.

Sp1 only partially counteracts the p53-dependent suppression of the S100A6 promoter

The role of Sp1 in the S100A6 promoter suppression by p53 was further analyzed using transactivation assays performed in the presence of overexpressed p53 and of increasing amounts (20-250 ng) of the pcDNA3.1(+)-Sp1 expression construct. As shown before (Fig. 1C), in the presence of $100 \mathrm{ng}$ of the CMV-p53 expression plasmid, the activity of the S100A6 promoter was inhibited 8-fold. In the presence of overexpressed Sp1 (Fig. 6A) only a partial relief of the p53-dependent suppression of the $S 100 A 6$ promoter was achieved. This effect was dose-dependent (Fig. 6B). In the presence of $200 \mathrm{ng}$ of the Sp1 expression construct, the p53-dependent suppression of the S100A6 promoter activity was only 1.8 -fold (to $55-60 \%$ of the promoter activity without p53). This effect was not magnified by further increase of the amount of the Sp1 expression vector.

NFkB only partially counteracts the p53-dependent suppression of the $S 100 A 6$ promoter

We then turned our attention to the role of the $\mathrm{NF} \times \mathrm{B}$ transcription factor (another factor indicated by others as mediating the p53 inhibitory effect on transcription) in the S100A6 promoter suppression by p53. Transcription regulation assays were performed as described before, in the presence of increasing amounts of pcDNA3.1(+)-NFkB p50 (5-150 ng) and of pcDNA3.1(+)NFKB p65 (2.5-100 ng) expression plasmids. Transfection performed with $25 \mathrm{ng}$ or higher amounts of the NFkB p65 expression construct resulted in a similar production of the encoded protein. Again, in the presence of overexpressed NFאB (Fig. 7A), only a partial, dose-dependent reversal of the p53-dependent suppression of the S100A6 promoter was achieved. In the presence of optimal amounts of the NFkB expression

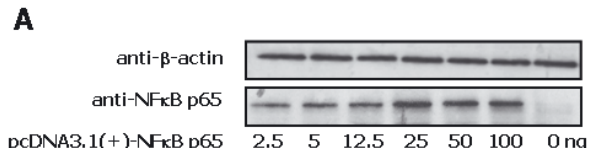

B

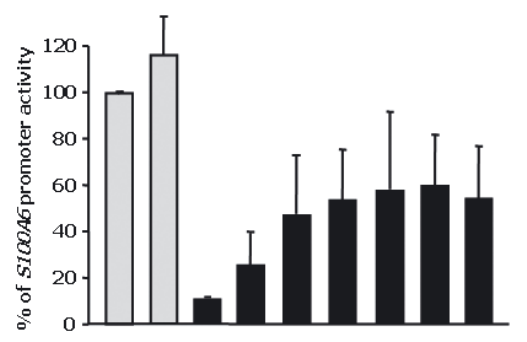

pGL2-CACY (-1371/+134) $250250250250250250250250250 \mathrm{ng}$ CMV-p53 $\quad 0 \quad 0 \quad 100100100100100100100 \mathrm{ng}$

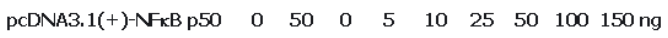

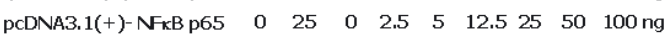
pcDNA3.1(+) $250175250243235218175100 \quad 0 \quad$ ng

Figure 7. Overexpression of NFкB partially counteracts the p53 inhibitory effect on the S100A6 promoter.

(A) Immunoblots of whole-cell extracts made from control HeLa cells as well as HeLa cells overexpressing p53 and $\mathrm{NF \kappa B}$ p50 and p65. The blots were probed with anti-NFкB p65 antibody. Duplicate blots were probed with anti- $\beta$-actin antibody. (B) Overexpression of NFKB counteracts the p53-dependent inhibition of the S100A6 promoter in a dose-dependent manner. HeLa cells were transfected with pGL2-CACY (-1371/+134) reporter plasmid, with CMV-p53 expression plasmid encoding wild type human p53, with different amounts of pcDNA3.1(+)-NFkB p50 and of pcDNA3.1(+)-NFKB p65 expression plasmids encoding wild type human NFKB p50 and p65 proteins, respectively, with phRL-CMV internal control vector, and, to equalize the total amount of DNA in each sample, with different amounts of 'empty' pcDNA3.1(+). Firefly luciferase activity was measured $24 \mathrm{~h}$ post-transfection and the results were normalized against Renilla luciferase activity. Bars represent the mean result ( \pm standard deviation) of 9 experiments. 


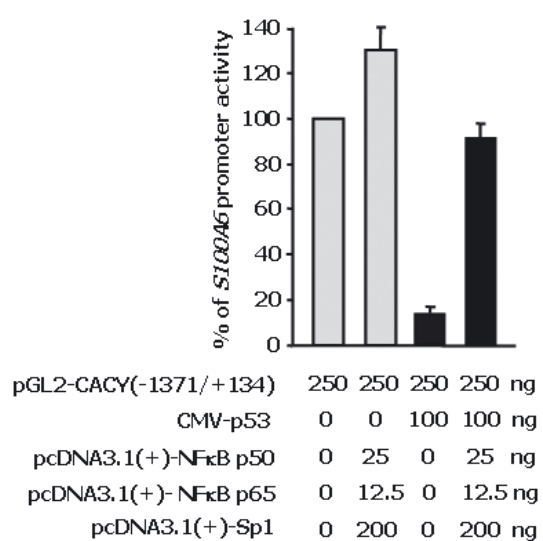

Figure 8. Simultaneous overexpression of $\mathrm{Sp} 1$ and NFkB completely counteracts the p53 inhibitory effect on the S100A6 promoter.

HeLa cells were transfected with pGL2-CACY $(-1371 /+134)$ reporter plasmid, with CMV-p53 expression plasmid encoding wild type human p53, with pcDNA3.1(+)-Sp1,

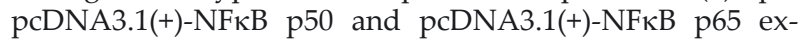
pression plasmids encoding wild type human $\mathrm{Sp1}$, NFkB p50 and p65 transcription factors, respectively, with phRLCMV internal control vector, and, to equalize the total amount of DNA in each sample, with 'empty' pcDNA3.1(+). Firefly luciferase activity was measured $24 \mathrm{~h}$ post-transfection and the results were normalized against Renilla luciferase activity. Bars represent the mean result $( \pm$ standard deviation) of 9 experiments.

constructs, the activity of the $\$ 100 A 6$ promoter was suppressed by p53 only 1.8 -fold (to $55-60 \%$ of its activity without p53). The plateau of de-inhibition was reached with $25 \mathrm{ng}$ of $\mathrm{NF \kappa B}$ p50 and $12.5 \mathrm{ng}$ of $\mathrm{NF \kappa B}$ p65 expression vectors (Fig. 7B).

Simultaneous action of Sp1 and NFkB fully counteracts the S100A6 promoter suppression by p53

To establish if Sp1 and NFKB are the only factors mediating p53-dependent suppression of the $\$ 100 A 6$ promoter, its activity was analyzed in the presence of overexpressed p53 and of the lowest amounts of expression plasmids pcDNA3.1(+)Sp1, pcDNA3.1(+)-NFкB p50 and pcDNA3.1(+)NFкB p65 (200 ng, $25 \mathrm{ng}$ and $12.5 \mathrm{ng}$, respectively) that, as shown in the previous experiments, maximally counteracted the p53-dependent suppression of the S100A6 promoter. Simultaneous overexpression of both transcription factors completely abolished the inhibitory action of p53 on the S100A6 promoter (Fig. 8).

Sp1 and NFkB binding to the S100A6 promoter is decreased in the presence of $\mathrm{p} 53$

To further elucidate the role of $\mathrm{Sp} 1$ and $\mathrm{NF \kappa B}$ in the p53-dependent suppression of the S100A6 promoter, electrophoretic mobility shift as-

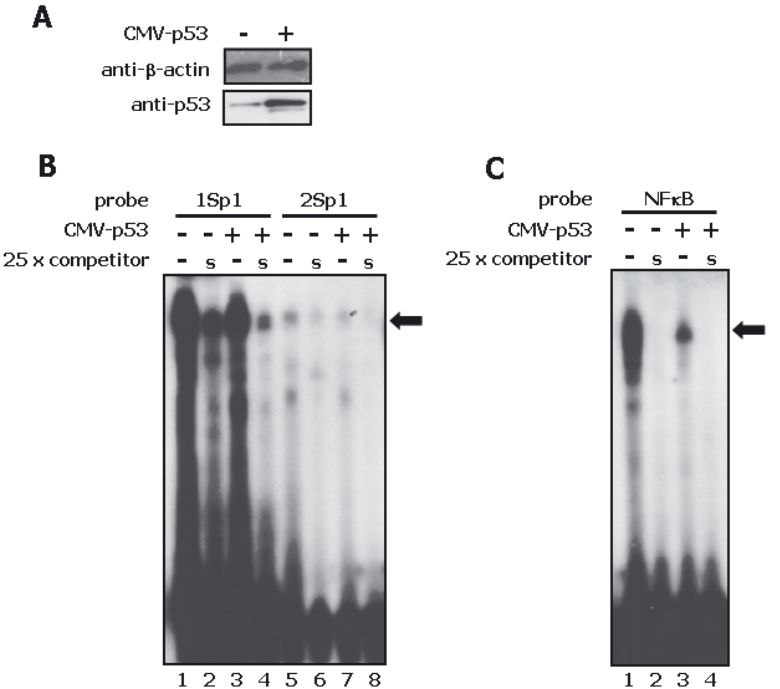

Figure 9. p53 decreases $\mathrm{Sp} 1$ and NFкB binding to their recognition sites in the $S 100 A 6$ promoter.

(A) Immunoblot of protein extracts made from control HeLa cells as well as HeLa cells overexpressing p53. The blot was probed with anti-p53 antibody and re-probed with anti- $\beta$-actin antibody. (B) Electrophoretic mobility shift assays performed with control HeLa nuclear extracts and with nuclear extracts made from HeLa cells transfected with p53 expression plasmid and the two overlapping probes identical to the $S 100 A 6$ promoter fragment containing putative Sp1-binding sites (GC-rich region located at -100 to -63 position). (C) Electrophoretic mobility shift assays performed with control HeLa nuclear extracts or with nuclear extracts made from HeLa cells transfected with p53 expression plasmid, and with the probe identical to the putative NFKB-binding site located at +66 to +77 position of the S100A6 promoter. S, specific competitor (cold probe). Arrows, specific shifted bands.

says were performed using probes identical to the putative Sp1-binding sites present in the GC-rich region of the S100A6 promoter (two overlapping probes covering together the whole GC-rich region), and to the putative NFKB-binding site located downstream of the transcription start site $(+66$ to +77$)$. The other NFKB-binding site located at the -460 to -451 position (Joo et al., 2003) was not included in this analysis, since we had previously shown that deletion of this site had no influence on the S100A6 promoter suppression by p53. Experiments were performed with HeLa nuclear extracts made from cells transfected with p53 expression vector and from control cells weakly expressing endogenous p53 (Fig. 9A). A weak-to-strong binding of endogenous transcription factors to the putative Sp1-binding sites was detected (Fig. 9B, lanes 1 and 5, black arrow). The presence of overexpressed p53 in the binding reaction decreased the amount of Sp1-DNA complexes (Fig. 9B, lanes 1 vs. 3, 5 vs. 7, black arrow). No other changes in the binding pattern were observed in the pres- 
ence of p53. A specific binding to the NFкB putative binding site was also detected (Fig. 9C, lane 1, black arrow). As described above for Sp1 binding to DNA, in the presence of overexpressed p53 the binding of NFKB to its recognition site was decreased (Fig. 9C, lane 1 vs., 3, black arrow). The results of the assays performed with HeLa cell extract containing high amount of endogenous p53 induced by $6 \mu \mathrm{M}$ camptothecin (Houser et al., 2001) were identical to these described above (not shown).

\section{DISCUSSION}

In this work we show that the promoter of the S100A6 gene encoding calcyclin, a member of the $\mathrm{S} 100$ family of $\mathrm{Ca}^{2+}$-binding proteins, is suppressed by $\mathrm{p} 53$ in a dose-dependent manner. Such dependence is an important additional argument in the discussion concerning the role of calcyclin in cell cycle regulation.

Calcyclin is overexpressed in many types of human cancers, and sometimes is considered a tumor marker and diagnostic factor (Wojda \& Kuznicki, 1993; Filipek \& Kuznicki, 1993; Weterman et al., 1993; Berta et al., 1997; Komatsu et al., 2000; Kim et al., 2002; Jang et al., 2004; Vimalachandran et al., 2005). Since p53 accumulates in more than $50 \%$ of all cancers, the elevation of p53 should be accompanied by a corresponding decrease of calcyclin. However, as shown by us in this paper, such correlation might be true only for the cases with accumulation of the wild type p53, which is not common. This could be so because p53 is mutated in more than $50 \%$ of malignant tumors (Hernandez-Boussard et al., 1999; Strano et al., 2007; Petitjean et al., 2007). The majority of these mutations are missense mutations located in the DNAbinding domain (Martin et al., 2002; Olivier et al., 2004). Since trans-repression by p53 usually does not require DNA binding, these mutants may retain their ability to suppress transcription. However, the majority of the mutants analyzed so far by other authors have lost, at least in part, this ability (Unger et al. 1993; Harris et al., 1996; Wang \& Beck, 1998; Subbaramaiah et al., 1999; Blagosklonny, 2000). Our data is consistent with their results, as we also showed that certain p53 mutants suppress the $A 100 A 6$ promoter 6 to 9 -fold weaker than the wild type p53. Therefore, an absence of correlation should be expected in cancer tissues, rather than an inverse correlation between p53 and calcyclin levels. In accordance with this expectation, in pancreas cancer, the only cancer type analyzed so far for the association between p53 and calcyclin, there was no correlation between nuclear calcyclin expression and p53 (Vimalachandran et al., 2005). This is consistent with the fact that in $50-80 \%$ of cancers of this organ, p53 mutants have been reported (Redston et al., 1994; Iwao et al., 1998).

It has been shown by other authors that the suppression of transcription by p53 might be a result of the diverse mechanisms listed in the introduction (Subbaramaiah et al., 1999; Xu et al., 2000; Li \& Lee, 2001; St Clair et al., 2004; Sengupta et al., 2005), and might be mediated by different proteins (Seto et al., 1992; Truant et al., 1993; Ragimov et al., 1993; Xiao et al., 1994; Farmer et al., 1996; Webster et al., 1996; Bargonetti et al., 1997; Ohlsson et al., 1998; Subbaramaiah et al., 1999; Xu et al., 2000; Zhang et al., 2000). Our data indicate that the S100A6 promoter is suppressed by p53 due to its interference with the function of Sp1 and NFкB. Therefore, the S100A6 promoter suppression by p53 is, in fact, the result of insufficient activation by the Sp1 and $\mathrm{NF} \kappa \mathrm{B}$ transcription activators. Electrophoretic mobility shift assays point to disturbed binding of these transcription factors to the $S 100 A 6$ promoter in the presence of p53: lower amounts of the Sp1-DNA and NFKB-DNA complexes are formed in the presence of p53 than in its absence. This indicates that either Sp1 and NFKB decrease their affinity for DNA or are sequestered by $\mathrm{p} 53$, most possibly due to the formation of $\mathrm{p} 53-\mathrm{Sp} 1$ and $\mathrm{p} 53-\mathrm{NF \kappa B}$ heterocomplexes. Such interaction between p53 and Sp1 has been previously described by other authors studying suppression of transcription by p53 (Bargonetti et al., 1997; Ohlsson et al., 1998; Xu et al., 2000; Sengupta et al., 2005).

In conclusion, we propose that the suppression of the S100A6 promoter and the resulting decrease of the amount of calcyclin could well be a mechanism by which p53 inhibits cell proliferation. The weak or no suppression of the S100A6 promoter by mutant p53 may be unable to initiate such a mechanism in cancers, leading to overexpression of calcyclin and, possibly, to the deregulation of cell cycle control. However, to confirm this hypothesis, a detailed analysis of p53-calcyclin interrelationship throughout the cell cycle should be performed.

\section{Acknowledgements}

Authors wish to thank Dr. Wiesława Lesniak (Nencki Institute of Experimental Biology, Warszawa, Poland) for S100A6 reporter vectors, Prof. Maciej Zylicz (International Institute of Molecular and Cell Biology, Warszawa, Poland) for p53 expression vectors and pGL3-p53BS reporter vector, and Dr. Jochen Seufert (Medical Policlinic of the University of Wuerzburg, Germany) for NFkB expression vectors. 
This work was supported by the State Committee for Scientific Research grant 3P04A 01225 and CMKP grant 501-2-1-22-32/04.

\section{REFERENCES}

Alvarez-Chaver P, Rodriguez-Pineiro AM, Rodriguez-Berrocal FJ, Martinez-Zorzano VS, Paez de la Cadena M (2007) Identification of hydrophobic proteins as biomarker candidates for colorectal cancer. Int J Biochem Cell Biol 39: 529-540.

Bargonetti J, Chicas A, White D, Prives C (1997) p53 represses Sp1 DNA binding and HIV-LTR directed transcription. Cell Mol Biol 43: 935-949.

Berta GN, Ghezzo F, D'Avolio A, Zulian P, Carbone V, Racca S, Vercellino V, Di Carlo F (1997) Enhancement of calcyclin gene RNA expression in squamous cell carcinoma of the oral mucosa, but not in benign lesions. $J$ Oral Pathol Med 26: 206-210.

Blagosklonny MV (2000) p53 from complexity to simplicity: mutant p53 stabilization, gain-of-function, and dominant-negative effect. FASEB J 14: 1901-1907.

Brown LM, Helmke SM, Hunsucker SW, Netea-Maier RT, Chiang SA, Heinz DE, Shroyer KR, Duncan MW, Haugen BR (2006) Quantitative and qualitative differences in protein expression between papillary thyroid carcinoma and normal thyroid tissue. Mol Carcinog 45: 613-626.

Cheng CW, Rifai A, Ka SM, Shui HA, Lin YF, Lee WH, Chen A (2005) Calcium-binding proteins annexin A2 and S100A6 are sensors of tubular injury and recovery in acute renal failure. Kidney Int 68: 2694-2703.

Cross SS, Hamdy FC, Deloulme JC, Rehman I (2005) Expression of $\mathrm{S} 100$ proteins in normal human tissues and common cancers using tissue microarrays: S100A6, S100A8, S100A9 and S100A11 are all overexpressed in common cancers. Histopathology 46: 256-269.

Donato R (2003) Intracellular and extracellular roles of S100 proteins. Microsc Res Tech 60: 540-551.

Farmer G, Colgan J, Nakatani Y, Manley JL, Prives C (1996) Functional interaction between p53, the TATA-binding protein (TBP), and TBP-associated factors in vivo. Mol Cell Biol 16: 4295-4304.

Farnaes L, Ditzel HJ (2003) Dissecting the cellular functions of annexin XI using recombinant human annexin XI-specific autoantibodies cloned by phage display. J Biol Chem 278: 33120-33126.

Ferrari S, Tagliafico E, Manfredini R, Grande A, Rossi E, Zucchini P, Torelli G, Torelli U (1992) Abundance of the primary transcript and its processed product of growth-related genes in normal and leukemic cells during proliferation and differentiation. Cancer Res 52: 11-16.

Filipek A, Kuznicki J (1993) Calcyclin - from basic research to clinical implications. Acta Biochim Polon 40: 321-327.

Filipek A, Puzianowska M, Cieslak B, Kuznicki J (1993) Calcyclin-Ca(2+)-binding protein homologous to glial S-100 beta is present in neurones. Neuroreport 4: 383386.

Ghezzo F, Lauret E, Ferrari S, Baserga R (1988) Growth factor regulation of the promoter for calcyclin, a growthregulated gene. J Biol Chem 263: 4758-4763.

Harris LC, Remack JS, Houghton PJ, Brent TP (1996) Wildtype p53 suppresses transcription of the human $\mathrm{O}^{6}$ methylguanine-DNA methyltransferase gene. Cancer Res 56: 2029-2032.
Heizmann CW, Fritz G, Schafer BW (2002) S100 proteins: structure, functions and pathology. Front Biosci 7: d1356-d1368.

Hernandez-Boussard T, Rodriguez-Tome P, Montesano R, Hainaut P (1999) IARC p53 mutation database: a relational database to compile and analyze p53 mutations in human tumors and cell lines. International Agency for Research on Cancer. Hum Mutat 14: 1-8.

Hirschhorn RR, Aller P, Yuan ZA, Gibson CW, Baserga R (1984) Cell-cycle-specific cDNAs from mammalian cells temperature sensitive for growth. Proc Natl Acad Sci USA 80: 6004-6008.

Hoppe-Seyler F, Butz K (1993) Repression of endogenous p53 transactivation function in HeLa cervical carcinoma cells by human papillomavirus type $16 \mathrm{E} 6$, human mdm-2, and mutant p53. J Virol 67: 3111-3117.

Houser S, Koshlatyi S, Lu T, Gopen T, Bargonetti J (2001) Camptothecin and Zeocin can increase p53 levels during all cell cycle stages. Biochem Biophys Res Commun 289: 998-1009.

Iwao T, Hanada K, Tsuchida A, Hirata M, Eguchi N, Kajiyama G (1998) The establishment of a preoperative diagnosis of pancreatic carcinoma using cell specimens from pancreatic duct brushing with special attention to p53 mutations. Cancer 82: 1487-1494.

Jang JS, Cho HY, Lee YJ, Ha WS, Kim HW (2004) The differential proteome profile of stomach cancer: identification of the biomarker candidates. Oncol Res 14: 491-499.

Kim J, Kim J, Yoon S, Joo J, Lee Y, Lee K, Chung J, Choe I (2002) S100A6 protein as a marker for differential diagnosis of cholangiocarcinoma from hepatocellular carcinoma. Hepatol Res 23: 274-286.

Komatsu K, Andoh A, Ishiguro S, Suzuki N, Hunai H, Kobune-Fujiwara Y, Kameyama M, Miyoshi J, Akedo H, Nakamura H (2000) Increased expression of S100A6 (Calcyclin), a calcium-binding protein of the S100 family, in human colorectal adenocarcinomas. Clin Cancer Res 6: 172-177.

Kuznicki J, Kordowska J, Puzianowska M, Wozniewicz BM (1992) Calcyclin as a marker of human epithelial cells and fibroblasts. Exp Cell Res 200: 425-430.

Lesniak W, Jezierska A, Kuznicki J (2000) Upstream stimulatory factor is involved in the regulation of the human calcyclin (S100A6) gene. Biochim Biophys Acta 1517: 73-81.

Li B, Lee MY (2001) Transcriptional regulation of the human DNA polymerase $\delta$ catalytic subunit gene POLD1 by p53 tumor suppressor and Sp1. J Biol Chem 276: 29729-29739.

Martin AC, Facchiano AM, Cuff AL, Hernandez-Boussard T, Olivier M, Hainaut P, Thornton JM (2002) Integrating mutation data and structural analysis of the TP53 tumor-suppressor protein. Hum Mutat 19: 149-164.

Ohlsson C, Kley N, Werner H, LeRoith D (1998) p53 regulates insulin-like growth factor-I (IGF-I) receptor expression and IGF-I-induced tyrosine phosphorylation in an osteosarcoma cell line: interaction between p53 and Sp1. Endocrinology 139: 1101-1107.

Ohuchida K, Mizumoto K, Yu J, Yamaguchi H, Konomi H, Nagai E, Yamaguchi K, Tsuneyoshi M, Tanaka M (2007) S100A6 is increased in a stepwise manner during pancreatic carcinogenesis: clinical value of expression analysis in 98 pancreatic juice samples. Cancer Epidemiol Biomarkers Prev 16: 6496-6454.

Okazaki K, Niki I, Iino S, Kobayashi S, Hidaka H (1994) A role of calcyclin, a $\mathrm{Ca}^{2+}$-binding protein, on the $\mathrm{Ca}^{2+}$ dependent insulin release from the pancreatic $\beta$ cell. $J$ Biol Chem 269: 6149-6152. 
Olivier M, Hussain SP, Caron de Fromentel C, Hainaut P, Harris CC (2004) TP53 mutation spectra and load: a tool for generating hypotheses on the etiology of cancer. IARC Sci Publ 157: 247-270.

Petitjean A, Achatz MI, Borresen-Dale AL, Hainaut P, Olivier M (2007) TP53 mutations in human cancers: functional selection and impact on cancer prognosis and outcomes. Oncogene 26: 2157-2165.

Ragimov N, Krauskopf A, Navot N, Rotter V, Oren M, Aloni Y (1993) Wild-type but not mutant p53 can repress transcription initiation in vitro by interfering with the binding of basal transcription factors to the TATA motif. Oncogene 8: 1183-1193.

Redston MS, Caldas C, Seymour AB, Hruban RH, da Costa L, Yeo CJ, Kern SE (1994) p53 mutations in pancreatic carcinoma and evidence of common involvement of homocopolymer tracts in DNA microdeletions. Cancer Res 54: 3025-3033.

Santamaria-Kisiel L, Rintala-Dempsey AC, Shaw GS (2006) Calcium-dependent and -independent interactions of the S100 protein family. Biochem J 396: 201-214.

Sengupta S, Shimamoto A, Koshiji M, Pedeux R, Rusin $\mathrm{M}$, Spillare EA, Shen JC, Huang LE, Lindor NM, Furuichi Y, Harris CC (2005) Tumor suppressor p53 represses transcription of RECQ4 helicase. Oncogene 24: $1738-1748$

Seto E, Usheva A, Zambetti GP, Momand J, Horikoshi N, Weinmann R, Levine AJ, Shenk T (1992) Wild-type p53 binds to the TATA-binding protein and represses transcription. Proc Natl Acad Sci USA 89: 12028-12032.

St Clair S, Giono L, Varmeh-Ziaie S, Resnick-Silverman L, Liu WJ, Padi A, Dastidar J, DaCosta A, Mattia M, Manfredi JJ (2004) DNA damage-induced downregulation of Cdc25C is mediated by p53 via two independent mechanisms: one involves direct binding to the cdc25C promoter. Mol Cell 16: 725-736.

Stradal TB, Gimona M (1999) $\mathrm{Ca}^{2+}$-dependent association of S100A6 (Calcyclin) with the plasma membrane and the nuclear envelope. J Biol Chem 274: 31593-31596.

Strano S, Dell'Orso S, Di Agostino S, Fontemaggi G, Sacchi A, Blandino G (2007) Mutant p53: an oncogenic transcription factor. Oncogene 26: 2212-2219.

Subbaramaiah K, Altorki N, Chung WJ, Mestre JR, Sampat A, Dannenberg AJ (1999) Inhibition of cyclooxygenase-2 gene expression by p53. J Biol Chem 274: 1091110915.

Szymańska K, Hainaut P (2003) TP53 and mutations in human cancer. Acta Biochim Polon 50: 231-238.

Thordarson G, Southard JN, Talamantes F (1991) Purification and characterization of mouse decidual calcyclin: a novel stimulator of mouse placental lactogen-II secretion. Endocrinology 129: 1257-1265.

Tomas A, Moss SE (2003) Calcium- and cell cycle-dependent association of annexin 11 with the nuclear envelope. J Biol Chem 278: 20210-20216.
Tonini GP, Fabretti G, Kuznicki J, Massimo L, Scaruffi P, Brisigotti M, Mazzocco K (1995) Gene expression and protein localisation of calcyclin, a calcium-binding protein of the S-100 family in fresh neuroblastomas. Eur J Cancer 31A: 499-504.

Truant R, Xiao H, Ingles CJ, Greenblatt J (1993) Direct interaction between the transcriptional activation domain of human p53 and the TATA box-binding protein. $J$ Biol Chem 268: 2284-2287.

Unger T, Mietz JA, Scheffner M, Yee CL, Howley PM (1993) Functional domains of wild-type and mutant p53 proteins involved in transcriptional regulation, transdominant inhibition, and transformation suppression. Mol Cell Biol 13: 5186-5194.

Wang Q, Beck WT (1998) Transcriptional suppression of multidrug resistance-associated protein (MRP) gene expression by wild-type p53. Cancer Res 58: 5762-5769.

Webster NJ, Resnik JL, Reichart DB, Strauss B, Haas M, Seely BL (1996) Repression of the insulin receptor promoter by the tumor suppressor gene product p53: a possible mechanism for receptor overexpression in breast cancer. Cancer Res 56: 2781-2788.

Weterman MA, Stoopen GM, van Muijen GN, Kuznicki J, Ruiter DJ, Bloemers HP (1992) Expression of calcyclin in human melanoma cell lines correlates with metastatic behavior in nude mice. Cancer Res 52: 1291-1296.

Weterman MA, van Muijen GN, Bloemers HP, Ruiter DJ (1993) Expression of calcyclin in human melanocytic lesions. Cancer Res 53: 6061-6066.

Wojda U, Kuznicki J (1993) Biochemical properties of calcyclin - a potential marker of some diseases. Acta Biochim Polon 40: 171-175.

Vimalachandran D, Greenhalf W, Thompson C, Luttges J, Prime W, Campbell F, Dodson A, Watson R, Crnogorac-Jurcevic T, Lemoine N, Neoptolemos J, Costello E (2005) High nuclear S100A6 (Calcyclin) is significantly associated with poor survival in pancreatic cancer patients. Cancer Res 65: 3218-3225.

Xiao H, Pearson A, Coulombe B, Truant R, Zhang S, Regier JL, Triezenberg SJ, Reinberg D, Flores O, Ingles CJ, Greenblatt J (1994) Binding of basal transcription factor TFIIH to the acidic activation domains of VP16 and p53. Mol Cell Biol 14: 7013-7024.

Xu D, Wang Q, Gruber A, Bjorkholm M, Chen Z, Zaid A, Selivanova G, Peterson C, Wiman KG, Pisa P (2000) Downregulation of telomerase reverse transcriptase mRNA expression by wild type p53 in human tumor cells. Oncogene 19: 5123-5133.

Zhang L, Yu D, Hu M, Xiong S, Lang A, Ellis LM, Pollock RE (2000) Wild-type p53 suppresses angiogenesis in human leiomyosarcoma and synovial sarcoma by transcriptional suppression of vascular endothelial growth factor expression. Cancer Res 60: 3655-3661. 